\title{
THE BACTERIOLOGY OF URINARY INFECTIONS IN PARAPLEGIA
}

\author{
BY \\ T. G. SCOTT* \\ From the Department of Clinical Pathology, the National Hospital for Nervous Diseases, \\ Queen Square, London
}

(RECEIVED FOR PUBLICATION JULY 10, 1959)

Two hundred and forty-seven strains of micro-organisms were isolated from the urinary tract of 121 patients with neurological complaints leading to paraplegia. The commonest infecting organism was $E$. coli and the commonest type of Proteus was $P$. mirabilis. Infections with more than one type of organism were present in $37 \%$ of urine specimens, and in such cases the incidence of $E$. coli was lower and that of Strep. faecalis higher than the incidences in infections with only one type of organism.

No evidence was found which might suggest that the various bacterial species encountered showed either an undue degree of synergism or of mutual antagonism.

Coliforms were the commonest primary pathogens, but Strep. faecalis and Proteus species occurred with the same frequency as the coliforms when they were considered as secondary invaders.

The variance between the incidence: of various species as reported by different workers is considered to be due to the different illnejzes and conditions which predispose to urinary tract infection. It appears that infections in the urinary tract by more than one type of organism at a time occur more frequently in those patients with the more chronic predisposing causes. (Some disparity in findings may also result from the differing taxonomic methods employed by different workers, but this is probably insufficiently important to account for the largest differences.)

In the course of routine examination of the urines of paraplegic patients in this hospital the high incidence of infected urines containing more than one type of organism was noted. It was decided to investigate paraplegic urines with specific reference to the frequency of various bacterial species, the possibility of the bacteria in multiple infections exerting mutual antagonism or synergism, and the relative importance of organisms as primary pathogens and as secondary invaders of the urinary tract. It is proposed to discuss the results against a review of the findings of certain other workers in other branches of medical and surgical practice.

\section{Material and Methods}

The number of patients with urinary tract infections investigated in one calendar year was 121. All of the patients had paraplegia in some form or another and in no case could it be shown that the infection began suddenly as, for example, in an acute pyelonephritis. Whenever possible specimens of urine were

*Present address: Department of Pathology, The Hospital for Sick Children, Great Ormond Street, London, W.C.1. obtained for culture from women by catheterization and from men by catheterization or by the " midstream " technique, but many patients at one time or another were on some form of bladder drainage, and this was then used as the means of obtaining the specimen. The organisms were isolated primarily on McConkey's bile salt lactose agar and blood agar. Species were identified by morphological and biochemical methods. The coliforms, i.e., all Gramnegative lactose-fermenting bacilli, were classiffed on the basis of indole production after two and seven days' growth in peptone water, the utilization of citrate (Koser's medium), the methyl-red reaction after growth in glucose-phosphate medium, and the VogesProskauer reaction using creatine and sodium hydroxide to hasten the reaction.

The Proteus group was classified according to the method of Cook (1948). Christensen's urea medium and lead acetate agar were used for the detection of species producing urease and $\mathrm{H}_{2} \mathrm{~S}$ respectively.

Coagulase-positive staphylococci were so designated after slide tests and negative strains subjected to a tube test.

$\beta$-Haemolytic streptococci were so designated on cellular and colonial morphology, and by $\beta$-haemolysis on blood agar. 
Streptococcus faecalis was differentiated from other streptococci by its ability to withstand a temperature of $60^{\circ} \mathrm{C}$. for 30 minutes.

The actual media and techniques used were as described by Mackie and McCartney (1953).

In this paper the phrase "primary pathogens" is taken to include the organisms isolated in the initial specimen of urine received from a patient and also those isolated after a period in which one or more urine specimens had proved sterile. All other organisms are regarded as secondary invaders. Although many patients were undergoing antibacterial therapy, no attempt is made here to separate secondary infection from superinfection.

\section{Results}

Frequency of Various Bacterial Species.-The frequency with which the various bacterial species were found is as follows:

Bacterial Flora in All Urines.-The total number of strains of micro-organisms isolated at varying times in the study period from the 121 patients was 247 , and these were recovered from a total of 181 specimens of urine. Of the patients, 49 were men and 72 women (see Table I).

TABLE I

NUMBER OF PATIENTS AND URINE SAMPLES INCLUDED IN SERIES

\begin{tabular}{|c|c|c|c|c|c|c|}
\hline \multirow{2}{*}{$\begin{array}{l}\text { No. of } \\
\text { Patients }\end{array}$} & \multicolumn{2}{|c|}{ Sex } & \multicolumn{3}{|c|}{$\begin{array}{l}\text { No. of Infected Urine } \\
\text { Samples Examined }\end{array}$} & \multirow{2}{*}{$\begin{array}{l}\text { No. of } \\
\text { Strains } \\
\text { of } \\
\text { Micro- } \\
\text { organ- } \\
\text { isms }\end{array}$} \\
\hline & $\mathbf{M}$ & $\mathbf{F}$ & Total & $\begin{array}{c}\text { Single } \\
\text { Infec- } \\
\text { tion }\end{array}$ & $\underset{\substack{\text { Infec- } \\
\text { tions }}}{\text { Multiple }}$ & \\
\hline 121 & $49(41 \%)$ & $72(59 \%)$ & 181 & $114(63 \%)$ & $67(37 \%)$ & 247 \\
\hline
\end{tabular}

TABLE II

INCIDENCE OF VARIOUS BACTERIAL SPECIES FOUND IN URINE IN PATIENTS WITH PARAPLEGIA

\begin{tabular}{|c|c|c|c|}
\hline Organism & $\begin{array}{c}\text { Overall } \\
\text { Incidence }\end{array}$ & $\begin{array}{l}\text { Incidence } \\
\text { in Single } \\
\text { Infections }\end{array}$ & $\begin{array}{c}\text { Incidence } \\
\text { in Multiple } \\
\text { Infections }\end{array}$ \\
\hline & No. & No. & No. \\
\hline $\begin{array}{l}\text { Coliforms } \\
\text { Strep. faecalis } \\
\text { Proteus (all types) } \\
\text { Ps. pyocyanea } \\
\text { Miscellaneous . . }\end{array}$ & $\begin{array}{ll}92 & (36 \%) \\
54 & (23 \%) \\
53 & (21 \%) \\
24 & (10 \%) \\
24 & (10 \%)\end{array}$ & $\begin{array}{rr}55 & (48 \%) \\
14 & (12 \%) \\
27 & (24 \%) \\
8 & (7 \%) \\
10 & (9 \%)\end{array}$ & $\begin{array}{ll}37 & (28 \%) \\
40 & (30 \%) \\
26 & (20 \%) \\
16 & (12 \%) \\
14 & (10 \%)\end{array}$ \\
\hline Total & $247(100 \%)$ & $114(100 \%)$ & $133(100 \%)$ \\
\hline
\end{tabular}

The incidence of the various bacterial strains isolated is given in Table II. As can be seen, the descending order of frequency is: coliforms, Strep. faecalis, Proteus, Ps. pyocyanea, and lastly a group of miscellaneous strains.

The coliforms were found to be divided as follows: Bact. coli $77 \%$, Bact. intermedium $13 \%$, and Bact. aerogenes $10 \%$; the Proteus species were as follows: $P$. mirabilis $85 \%, P$. vulgaris $10 \%$, and $P$. morgani $5 \%$.

Of the miscellaneous group, comprising 24 strains, seven were coagulase-positive staphylococci, 12 coagulase-negative staphylococci, three $\beta$-haemolytic streptococci, one a candida, and one a corynebacterium.

Bacterial Flora in Urines Containing Only One Type of Organism.-A single infecting organism was found in 90 patients, and from them 114 strains were isolated at different times. The incidence of the bacterial strains in these patients was: coliforms, Proteus, Strep. faecalis, the miscellaneous group, and Ps. pyocyanea, again in descending order of frequency. The actual frequencies found are shown in Table II. It will be seen that the coliform group formed by far the commonest single infecting organism, with the Proteus group next in order of frequency.

Bacterial Flora in Urines Containing More Than One Type of Organism.-A total of 133 strains was obtained from 67 specimens of urine containing more than one type of organism. The frequency of the various organisms found in multiple infections of the urinary tract was, in descending order: Strep. faecalis, coliforms, Proteus, Ps. pyocyanea, and the miscellaneous group. The incidence of coliforms was decreased considerably, while that of Strep. faecalis was increased. From the figures given in Table II it can be calculated that these changes in incidence are statistically significant $(P=<0.01$ in both cases). It will also be noticed that Proteus species have retained the same frequency which they possessed in single infections.

Analysis of Frequency of Association Between Various Species.-It is possible to show mutual antagonism between certain species in vitro; for example, that between certain strains of Pseudomonas and Proteus. Similarly, it is possible to show a "synergism" between species, e.g., the "satellitism" of Haemophilus influenzae around colonies of staphylococci. It was considered possible that similar antagonisms or synergism might occur in vivo.

It was decided that this problem could best be considered by analysing the results in the following manner. One strain at a time was selected for reference, and the number of other strains that were found in association with it was noted. Expressing the numbers so found as percentages of the number in the reference strain enabled direct comparisons to be made. The 
TABLE III

FREQUENCY OF ASSOCIATION OF DIFFERENT SPECIES IN MULTIPLE INFECTIONS

\begin{tabular}{|c|c|c|c|c|}
\hline $\begin{array}{c}\text { Percentage of Other } \\
\text { Strains Associated } \\
\text { with: }\end{array}$ & Coliforms & $\begin{array}{c}\text { Strep. } \\
\text { faecalis }\end{array}$ & Proteus & $\begin{array}{c}\text { Ps. } \\
\text { pyocyanea }\end{array}$ \\
\hline $\begin{array}{ll}\text { Coliforms } & \ldots \\
\text { Strep. faecalis } & \ldots \\
\text { Proteus } & \ldots \\
\text { Ps. pyocyanea } & \ldots\end{array}$ & $\begin{array}{l}\overline{53} \\
38 \\
31\end{array}$ & $\begin{array}{l}\frac{52}{38} \\
50\end{array}$ & $\begin{array}{l}24 \\
\frac{23}{13}\end{array}$ & $\begin{array}{r}13 \\
20 \\
8 \\
-\end{array}$ \\
\hline
\end{tabular}

results are given in Table III. By way of example it can be seen that, of all the strains found in association with the coliforms, $24 \%$ were Proteus species.

From inspection of Table III it would appear that the association between coliforms and Ps. pyocyanea is less frequent (31\%) than the association between coliforms and Strep. faecalis $(50 \%)$, for example. Also, when the coliforms are considered as the reference strain, it is seen that only $13 \%$ of organisms associated with them were Ps. pyocyanea as against $24 \%$ for Proteus. A similar apparent antagonism between Proteus and Ps. pyocyanea seems possible, as does an apparent synergism between Strep. faecalis and Ps. pyocyanea.

From the figures in the accompanying tables it is possible to calculate the expected frequencies of association between each type of organism. When this is done it is found that the expected frequencies agree remarkably closely with the observed frequencies, and that therefore a significantly abnormal amount of association between the species and the apparent antagonisms and synergisms discussed above did not exist.

Relative Importance of Organisms as Primary Pathogens and as Secondary Invaders-The coliforms were found to be the commonest primary invader, with Strep. faecalis and Proteus

TABLE IV

PERCENTAGE FREOUENCY OF VARTOUS SPECIES AS PRIMARY AND SECONDARY INVADERS

\begin{tabular}{c|c|c|c|c|c}
\hline & Coliforms & $\begin{array}{c}\text { Strep. } \\
\text { faecalis }\end{array}$ & Proteus & $\begin{array}{c}\text { Ps. } \\
\text { pyocyanea }\end{array}$ & $\begin{array}{c}\text { Miscel- } \\
\text { laneous }\end{array}$ \\
\hline $\begin{array}{c}\text { Primary } \\
\text { invaders }\end{array}$ & 42 & 15 & 18 & 11 & 14 \\
$\begin{array}{c}\text { Secondary } \\
\text { nvaders }\end{array}$ & 29 & 26 & 29 & 10 & 6 \\
\hline
\end{tabular}

next equal in importance. As secondary invaders, however, the three organisms occurred in almost equal frequency (Table IV).

\section{Discussion}

In this paper no attempt is made to differentiate between true infections and "benign bacteriuria," since any particular organism occurring in a benign bacteriuria is, theoretically at least, in a position to initiate a true infection.

The observed frequency of occurrence of coliforms as the commonest infecting organisms

TABLE V

PERCENTAGE FREQUENCY OF VARIOUS ORGANISMS IN URINE AS FOUND BY VARIOUS AUTHORS

\begin{tabular}{|c|c|c|c|c|c|c|c|c|c|c|}
\hline \multirow[t]{2}{*}{ Author } & Coliforms & $\begin{array}{l}\text { Strep. } \\
\text { faecalis }\end{array}$ & Proteus & $\begin{array}{c}\text { Ps. } \\
\text { pyocyanea }\end{array}$ & $\begin{array}{l}\text { Staphy- } \\
\text { lococci }\end{array}$ & $\begin{array}{l}\text { Strepto- } \\
\text { cocci }\end{array}$ & Others & \multirow[t]{2}{*}{$\begin{array}{c}\text { Single } \\
\text { Infections }\end{array}$} & \multirow[t]{2}{*}{$\begin{array}{c}\text { Multiple } \\
\text { Infections }\end{array}$} & \multirow[t]{2}{*}{$\begin{array}{l}\text { Nature of } \\
\text { Cases }\end{array}$} \\
\hline & $\mathbf{S} \quad \mathbf{M}$ & $\mathbf{M}$ & $\mathbf{M}$ & $\mathbf{M}$ & $\mathbf{S} \mathbf{M}$ & $\mathbf{S} \mathbf{M}$ & $\mathbf{S} \mathbf{M}$ & & & \\
\hline Hill et al. & 90 & - & 3 & 一 & 一 & - & 7 & - & 一 & Non-neurological \\
\hline Rantz (1942) & $\begin{array}{ll}78 & 22\end{array}$ & 7 & 2 & 一 & 29 & 30 & 6 & 62 & 38 & Pyelonephritis and \\
\hline $\begin{array}{l}\text { Badal et al. } \\
\text { (1944) }\end{array}$ & 27 & 9 & 24 & 2 & 14 & 15 & 9 & - & 一 & $\begin{array}{l}\text { Spinal cord } \\
\text { injuries }\end{array}$ \\
\hline $\begin{array}{l}\text { Gould (1951) } \\
\text { Gould et al. }\end{array}$ & ${ }_{51}^{68} 81$ & $75^{56}$ & $2_{19}^{17}$ & ${ }_{14}^{2}$ & 1828 & $1 \underline{-}^{28}$ & $\overline{11}$ & - & 二 & $\begin{array}{l}\text { ? nature of cases } \\
\text { Non-neurological }\end{array}$ \\
\hline $\begin{array}{c}(1952) \\
\text { Marshall } \\
\text { (1952) }\end{array}$ & 37 & 9 & 8 & 20 & 5 & 5 & 16 & 83 & 17 & Prostatectomy \\
\hline $\begin{array}{c}\text { Alesbury } \\
\text { (1952) }\end{array}$ & 23 & 35 & 一 & - & 5 & 37 & 一 & - & 一 & $\begin{array}{l}\text { Late pregnancy and } \\
\text { puerperium }\end{array}$ \\
\hline Yow* (1952) & $\begin{array}{l}70 \\
36\end{array}$ & - & $\begin{array}{r}9 \\
35\end{array}$ & $\begin{array}{l}15 \\
32\end{array}$ & 二 & - & $\begin{array}{l}10 \\
36\end{array}$ & - & 二 & $\begin{array}{l}\text { In } 1948 \text { ? nature } \\
1950 \text { of cases }\end{array}$ \\
\hline $\begin{array}{l}\text { Rhoads et al. } \\
\text { (1952) }\end{array}$ & 50 & $\overline{22}$ & 3 & 15 & 7 & - & 3 & $\overline{79}$ & 21 & ? nature of cases \\
\hline $\begin{array}{c}\text { Barnard et } \\
\text { al. (1953) }\end{array}$ & 41 & 5 & 3 & 0 & 20 & 7 & 24 & 一 & 一 & Diabetic women \\
\hline Ghormley et & 19 & 11 & - & 4 & 45 & 14 & 7 & 50 & 50 & $\begin{array}{l}\text { Chronic } \\
\text { prostatitis }\end{array}$ \\
\hline Sanford et al. & 5135 & $9 \quad 10$ & 20 & 7 & 520 & -- & 108 & 80 & 20 & ? nature of cases \\
\hline $\begin{array}{l}\text { Scott (1959) } \\
\text { (this series) }\end{array}$ & $48 \quad 28$ & 1230 & 2420 & $\begin{array}{ll}7 & 12\end{array}$ & - & - & 910 & 63 & 37 & Paraplegia \\
\hline
\end{tabular}

* The figures here are expressed as a percentage of the total number of urines cultured.

$\mathbf{S}=$ Single infections. $\mathbf{M}=\mathbf{M u l t i p l e}$ infections. (Where $\mathbf{S}$ and $\mathbf{M}$ are not specified in dividually the single figure refers to the total incidence f that particular strain.) 
is to be expected. Similarly the increased frequency of isolation of Strep. faecalis, Proteus, and $P$ s. pyocyanea in multiple infections might be anticipated. These findings are, nevertheless, at variance with those of certain other workers (Table V). Gould (1951), for instance, in a series of 658 cases of urinary tract infection, found Bact. coli communis in $68 \%$ of single infections, whereas in multiple infections the figure rose to $84 \%$. The patients in his series were in a general hospital, and it seems probable that most were not neurological cases and not of the same order of chronicity as in the paraplegic patients in this series, and that the figures were based on the results of the initial urinary specimen examined in each case. Other series show varying figures for non-neurological cases. Marshall (1952) isolated coliforms in $38 \%$ of prostatectomy cases, whilst Hill, Seidman, Stadnichenko, and Ellis (1929) isolated Escherichia in $50 \%$ and Aerobacter in $39.5 \%$ of non-neurological cases, i.e., a total of $89.5 \%$ for coliforms as a whole, but this latter investigation was in the pre-antibiotic era. On the other hand, Alesbury (1952) isolated coliforms in only $23 \%$ of cases in late pregnancy and in the puerperium. In his series coliforms were third in succession to streptococci (throat type, $37 \%)$ and enterococci (35\%). Rantz (1942) reported an incidence of $78 \%$ of coliforms in single infections, a figure which fell to $22 \%$ for multiple infections. His work shows the largest disparity with this series, but was confined to patients with pyelonephritis and cystitis with or without septicaemia (Table V).

Strep. faecalis is found more often in the urine as a secondary invader than as a primary pathogen. There is general agreement upon this in the findings of other workers (Table V). There is general agreement also that this organism is less commonly found than the coliforms. A notable exception is the series of Alesbury (1952), who found an incidence of $35 \%$ for Strep. faecalis ; and it is probably very significant that his findings are in women in late pregnancy and the puerperium. That this is probably not due to a sex difference is shown by the work of Barnard, Story, and Root (1953), who found an incidence for Strep. faecalis of only $5 \%$ in 52 diabetic women.
There are fairly wide differences in the frequencies given by various workers for the Proteus group, and it is difficult to draw any conclusions concerning it. However, it does seem possible to make the generalization that this group is found with increased frequency in those patients with the more chronic conditions-a generalization that can, in fact, be applied to all types of organisms other than the coliforms.

From Table $\mathrm{V}$ it appears that there is a slight correlation between the incidence of multiple infections and the duration of the predisposing causes of the infections. The lowest incidence of multiple infections (17\%) is seen in Marshall's (1952) series in which the patients were undergoing prostatectomy. In this series 67 out of the 181 infected urine specimens contained more than one type of organism (27\%), whereas in the series of Ghormley, Cook, and Needham (1954) an incidence of $50 \%$ for multiple infections was found in a series of cases of chronic prostatitis, in which, it is interesting to note, staphylococci (of all types) were frequently encountered $(45 \%)$.

As stated earlier, a significant degree of association between the various bacterial species was not shown to exist. This does not preclude such an association being found in a much larger series.

I should like to thank Professor J. N. Cumings for his constructive criticism in the preparation of this paper, and also Miss E. M. Taylor for her clerical work.

\section{REFERENCES}

Alesbury, R. J. (1952). West. J. Surg., 60, 54.

Badal, D., Munro, D., and Lamb, M. E. (1944). New Engl. J. Med. 230, 688 .

Barnard, D. M., Story, R. D., and Root, H. F. (1953). Ibid., 248, 136.

Cook, G. T. (1948). J. Path. Bact., 60, 171

Ghormley, K. O., Cook, E. N., and Needham, G. M. (1954). Amer. J. clin. Path., 24, 186.

Gould, J. C. (1951). Edinb. med. J., 58, Trans. med.-chir. Soc. Edinb., session CXXX, 1950-51, p. 62.

_ Macleod, J. G., and O'Flynn, J. D. (1952). Brit. J. Urol., 24, 138.

Hill, J. H., Seidman, L. R., Stadnichenko, A. M. S., and Ellis, M. G. (1929). J. Bact., 17, 205.

Mackie, T. J., and McCartney, J. E. (1953). Handbook of Practical Bacteriology, 9th ed. E. \& S. Livingstone, Edinburgh and London.

Marshall, M., Jr. (1952). J. Urol. (Baltimore), 67, 713.

Rantz, L. A. (1942). Advanc. intern. Med., 1, 137.

Rhoads, P. S., Billings, C. E., and O'Conor, V. J. (1952). J. Amer. med. Ass., 148, 165.

Sanford, J. P., Favour, C. B., Mao, F. H., and Harrison, J. H. (1956). Amer. J. Med., $20,88$.

Yow, E. M. (1952). J. Amer. med. Ass., 149, 1184. 